\title{
A shift in anterior-posterior positional information underlies the fin-to-limb evolution
}

\author{
Koh Onimaru ${ }^{1,2}$, Shigehiro Kuraku ${ }^{3}$, Wataru Takagi ${ }^{4}$, Susumu Hyodo ${ }^{4}$, \\ James Sharpe ${ }^{2,5 *}$, Mikiko Tanaka ${ }^{1 *}$
}

${ }^{1}$ Graduate School of Bioscience and Biotechnology, Tokyo Institute of Technology, Yokohama, Japan; ${ }^{2} E M B L-C R G$ Systems Biology Research Unit, Centre for Genomic Regulation, and Universitat Pompeu Fabra, Barcelona, Spain; ${ }^{3}$ Phyloinformatics Unit, RIKEN Center for Life Science Technologies, Kobe, Japan; ${ }^{4}$ Laboratory of Physiology, Atmosphere and Ocean Research Institute, The University of Tokyo, Chiba, Japan; ${ }^{5}$ Institució Catalana de Recerca i Estudis Avançats, Barcelona, Spain

*For correspondence: james. sharpe@crg.eu (JS); mitanaka@ bio.titech.ac.jp (MT)

Competing interests: The authors declare that no competing interests exist.

Funding: See page 11

Received: 16 February 2015

Accepted: 15 July 2015

Published: 18 August 2015

Reviewing editor: Marianne E Bronner, California Institute of Technology, United States

(c) Copyright Onimaru et al. This article is distributed under the terms of the Creative Commons Attribution License, which permits unrestricted use and redistribution provided that the original author and source are credited.
Abstract The pectoral fins of ancestral fishes had multiple proximal elements connected to their pectoral girdles. During the fin-to-limb transition, anterior proximal elements were lost and only the most posterior one remained as the humerus. Thus, we hypothesised that an evolutionary alteration occurred in the anterior-posterior (AP) patterning system of limb buds. In this study, we examined the pectoral fin development of catshark (Scyliorhinus canicula) and revealed that the AP positional values in fin buds are shifted more posteriorly than mouse limb buds. Furthermore, examination of Gli3 function and regulation shows that catshark fins lack a specific AP patterning mechanism, which restricts its expression to an anterior domain in tetrapods. Finally, experimental perturbation of AP patterning in catshark fin buds results in an expansion of posterior values and loss of anterior skeletal elements. Together, these results suggest that a key genetic event of the fin-to-limb transformation was alteration of the AP patterning network.

DOI: 10.7554/eLife.07048.001

\section{Introduction}

Regulatory interactions between transcriptional factors play important roles for interpreting a morphogen gradient as positional information (Balaskas et al., 2012). Changes in these regulatory interactions may therefore be key players for patterning changes during morphological evolution. The fin-to-limb transformation is a prominent but still unsolved example of morphological evolution. 150 years ago Carl Gegenbaur subdivided the skeletal elements of shark pectoral fins into three segments along the anterior-posterior (AP) axis: propterygium, mesopterygium, and metapterygium (Gegenbaur, 1865) (Figure 1A), which are also found in the majority of chondrichthyans, none-teleost actinopterygians, placoderms, and acanthodians (Orvig, 1962; Coates, 1994, 2003). Therefore, possession of propterygium, mesopterygium, and metapterygium is considered to be a plesiomorphic state for gnathostomes. In the sarcopterygians (lobe-finned fishes including tetrapods), the propterygium and mesopterygium have been lost (Coates, 2003), thus, suggesting that anterior positional values have been lost or reduced during tetrapod evolution.

In mouse limb buds, Hand2, Gli3, and Shh are key genes for controlling AP patterning (Riddle et al., 1993; Te Welscher et al., 2002). One of the earliest patterning events is the mutual 
eLife digest Humans, mice, and other animals with four limbs belong to a group of land-dwelling animals known as the tetrapods. This group of animals evolved from ancient fish and one crucial adaptation to life on land involved the modification of fins to form limbs. The front pair of limbs (the 'arms') evolved from the 'pectoral' fins of the ancient fish. These fins contain numerous bones that fan out from a set of bones called the pectoral girdle. However, most of the bones nearer the front side (the thumb side in the human limb) were lost in the ancestors of tetrapods as they moved onto land. Only the bone nearest the back remained as the 'humerus', which forms the upper part of the limb (i.e., the upper arm of humans).

In the embryos of mice and other animals, the limbs develop from structures called limb buds. For the limb to develop properly, the cells in the limb bud need to receive specific instructions that depend on their position in the bud. A protein called Gli3R provides cells with information about their position along the 'anterior-posterior' (or thumb-to-little finger) axis of the bud. This protein regulates several genes that are involved in limb development, and this results in different genes being expressed in cells along the anterior-posterior axis. For example, Alx4 is only expressed in a small area at the anterior end of the bud, while Hand2 expression is found in a large area towards the posterior part.

Gli3R is also found in a fish called the catshark, but it is not clear how it controls the formation of fins. Onimaru et al. show that the pattern of gene expression in the catshark fin bud is different to that of the mouse limb bud. For example, Alx 4 is expressed in a larger area of the fin bud that extends further towards the posterior, while Hand2 is only found in a much smaller area at the posterior end of the bud. The experiments also suggest that Gli3R is active in a much larger area of the fin bud than in the limb bud.

Next, Onimaru et al. used a drug on the catshark embryos to increase the activity of another protein that can inhibit Gli3R. The fin buds of these shark had anterior shift in several gene expression domains, and the fins that formed were missing several anterior bones and had only a single bone connected to the pectoral girdle. Onimaru et al.'s findings suggest that during the evolution of the tetrapods, there may have been a shift in the anterior-posterior patterning of the fin bud to form a limb. An important area for future work will be to use genome-wide studies to study the fin/limb buds of other species.

DOI: 10.7554/eLife.07048.002

transcriptional repression between Gli3 in the anterior tissue and Hand2 in the posterior (Te Welscher et al., 2002; Osterwalder et alo, 2014). This early polarity in expression contributes to the subsequent posterior localized expression of Shh, and this morphogen in turn reinforces the anteriorly restricted Gli3 protein activity (Shh inhibits the default processing of the Gli3 protein to its repressor form (Gli3R), thus, creating a gradient of Gli3R along the AP axis) (Wang et al., 2000). Several studies on fin development of actinopterygians and chondrichthyans have revealed that posterior Shh expression is conserved among gnathostomes (Dahn et al., 2007; Davis et al., 2007; Yonei-Tamura et al., 2008; Sakamoto et al., 2009a). However, in fish fin development, the detailed roles of Shh signalling for AP patterning are not well studied and the role of the Hand2-Gli3 mutual interaction remains to be elucidated.

\section{Results and discussion}

To investigate changes in AP patterning during the fin-to-limb transition, we first cloned a number of AP patterning genes from the non-model species Scyliorhinus canicula (Figure $1 \mathrm{~B}-\mathrm{H}$ and Figure 1-figure supplement 1 for phylogentic analyses). In the mouse limb bud, Alx4, Pax9, Hand1, and Zic3 are positively regulated by Gli3R (Te Welscher et al., 2002; Fernandez-Teran et al., 2003; McGlinn et alo, 2005; Vokes et al., 2008) and thus are expressed in a localized anterior domain (one-third of the axis), while Hand2 and Tbx2 show broad posterior expression domains (two-thirds and one-half of the axis, respectively). In stage $30 \mathrm{~S}$. canicula embryos (staged according to Ballard et al., 1993), we found instead that the anterior genes Alx4, Pax9, Hand1, and Zic3 were expressed in broad domains, which extend more posteriorly than in the mouse (half the fin bud for $A / \times 4$, two-thirds for Pax9 and Hand1, and the whole axis for Zic3, Figure 1B-E). By contrast, the Hand2 and Tbx2 

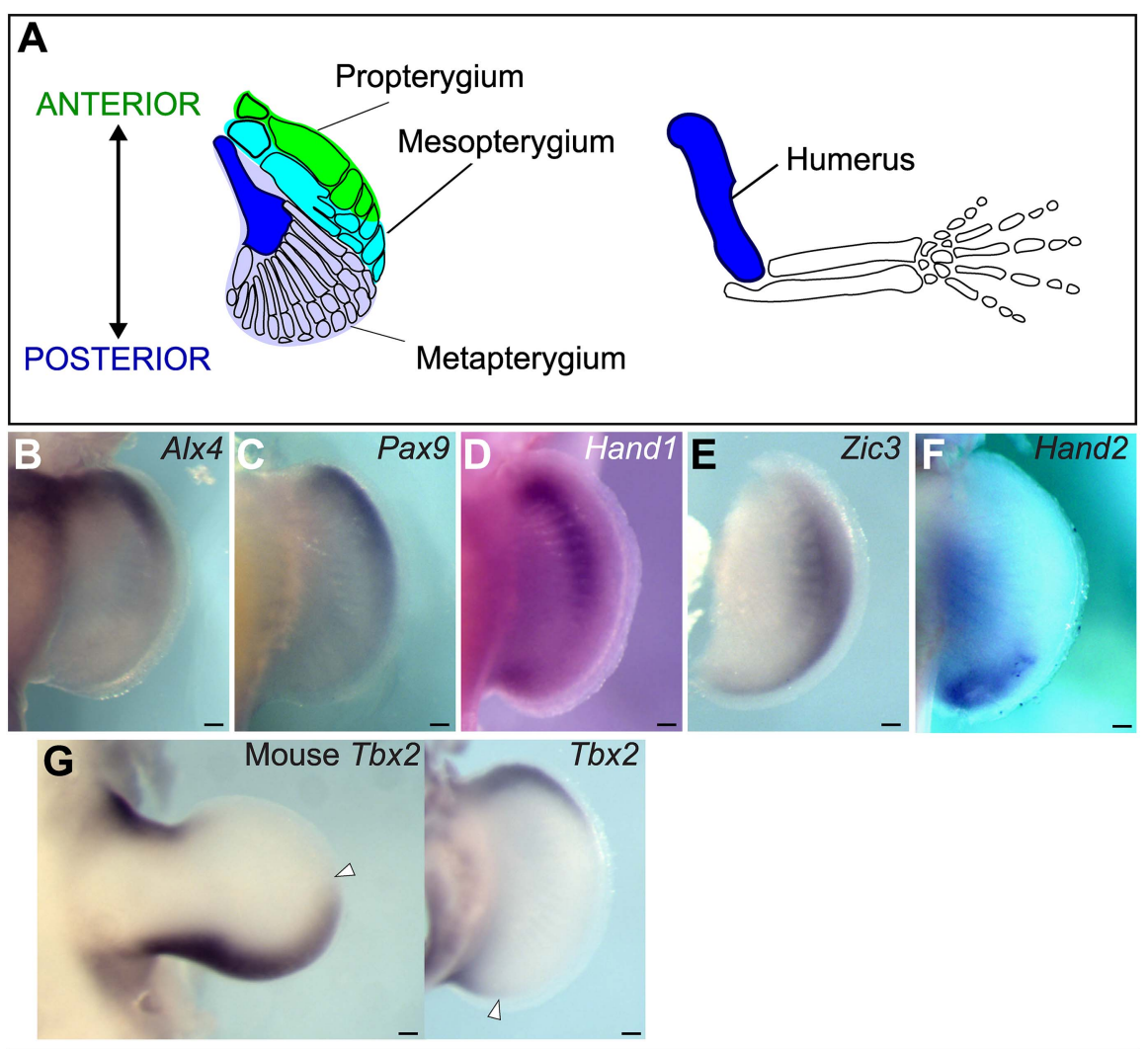

H

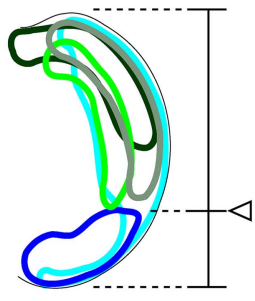

S. canicula

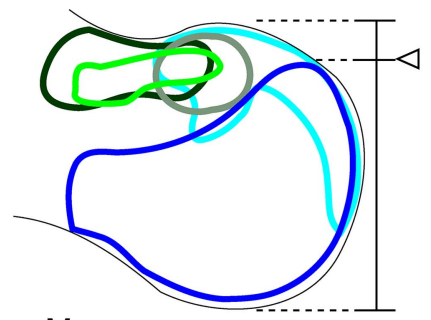

Mouse
Alx4

Hand 1

Pax9

Zic3

Hand2

Figure 1. Anterior-posterior patterning in Scyliorhinus canicula pectoral fin buds. (A) Skeletal patterns of S. canicula pectoral fin and mouse limb. Blue colours, homologous elements. (B-G) In situ hybridisation for Alx4 (B), Pax9 (C), Hand1 (D), Zic3 (E), Hand2 (F), and Tbx2 (G) in S. canicula pectoral fin buds at stage 30 and mouse limb bud at E11.5 (left panel in G). Arrowheads in G, anterior boundary of posterior Tbx2 expression. Dorsal view; anterior is to the top. Scale bars, $100 \mu \mathrm{m}$. (H) Schematic of the gene expression patterns. Arrowheads, Hand2 expression boundary. Expressions of mouse limb buds at E11.5 are after EMBRYS database (Yokoyama et al., 2009; Fernandez-Teran et al., 2003).

DOI: 10.7554/eLife.07048.003

The following figure supplements are available for figure 1:

Figure supplement 1. Molecular phylogenetic trees of relevant S. canicula genes.

DOI: 10.7554/eLife.07048.004

Figure supplement 2. Temporal expression analysis of $A 1 \times 4$, Pax9, Hand2, and Hoxa13 in S. canicula pectoral fins. DOI: 10.7554/eLife.07048.005

Figure supplement 3. Temporal expression analysis of Alx4, Pax9, Hand2, and Hoxa13 in chick limb buds. DOI: 10.7554/eLife.07048.006 
domains were more posteriorly restricted in $S$. canicula fin buds than in mouse limb buds (Figure 1F,G). All of these 6 AP patterning genes show the same trend-their expression boundaries are more posterior in S. canicula fin buds (Figure $1 \mathrm{H}$ ), apparently reflecting a gross shift in the AP coordinate system. We chose 3 of these genes to test at multiple time-points to determine whether this was a transient gene expression state (Figure 1-figure supplements 2, 3), but in all cases these shifts were observed from stage 29 to stage 31 (which covers 30 days of $S$. canicula development). In particular, stage 29 is a stage where Sox 9 expression (a prechondrogenic marker) starts in the proximal part of the pectoral fin buds (Figure 1-figure supplement 2E), which suggest that the observed shift of AP values would affect proximal skeletal elements as well as distal.

Since the above AP patterning genes are regulated by Shh-Gli3 pathway (Te Welscher et al., 2002; Fernandez-Teran et al., 2003; McGlinn et al., 2005; Galli et al., 2010), we cloned Gli3 from S. canicula fin buds (Figure 2A and Figure 2-figure supplement 1A for phylogenetic tree) and analysed its expression in pectoral fin buds. In striking contrast to tetrapod limb buds (Büscher et al., 1997; Schweitzer et al., 2000), Gli3 expression is not restricted to the anterior region-thus again indicating a general posterior shift of AP positional values in the $S$. canicula. To address whether this situation is conserved in other chondrichthyans, we also cloned and analysed the expression of Gli3 in pectoral fin buds of a holocephalian, Callorhinchus milii, which has propterygium (Figure 2B), and again found expression in the posterior part of pectoral fin bud at stage 31 (staged according to Didier et al., 1998; Figure 2B). Since Hand2 is expressed posteriorly and thus now overlaps with Gli3, this strongly suggests that the Hand2-Gli3 mutual inhibition seen in tetrapods is weak or non-existent in chondrichthyans.

In chick and mouse limb buds, Gli2 does not play a major role in AP patterning because of its weak processing efficiency to produce its repressor form (Wang et al., 2000). However, in zebrafish, Gli2 does indeed act as a repressor (Maurya et al., 2013), so we checked whether Gli2 could be playing the repressor role in S. canicula fin buds. First, we analysed Gli2 expression in S. canicula embryos and found it to be uniform until stage 29 (Figure 2C) and then subsequently restricted to the posterior region (Figure 2C). Second, we checked whether Gli3 and Gli2 of S. canicula have the repressor function, by measuring their processing efficiencies. We analysed the processing determinant domain (PDD), which determines the differential processing efficiencies of Gli3 and Gli2 in mice and humans (Pan and Wang, 2007). We inserted the PDDs from human Gli2 and S. canicula Gli2 or Gli3 into the human Gli3 PDD region (Figure 2D and Figure 2-figure supplement 1 for the amino acid sequences), transfected these constructs into HEK293 cells, and treated the cells with forskolin (FSK) to induce Gli processing. Human and S. canicula Gli2 PDD did not induce Gli3R, whereas their Gli3 PDDs did (Figure 2E). Thus, in S. canicula (as in chick and mouse), Gli3, but not Gli2, plays the major role in repressor production.

We next wished to explore if a genetic explanation could be found for the lack of Gli3 repression in the posterior part of pectoral fin buds of $S$. canicula and C. milii. To compare Gli3 enhancers in chondrichthyans and tetrapods, we used the VISTA enhancer browser (Visel et al., 2007) and found a limb-specific Gli3 enhancer, element 1586, which replicates anterior Gli3 expression in mouse limb buds. We identified the homologues of element 1586 in S. canicula and C. milii and compared them with those from other vertebrates. Consistent with the slow evolutionary rate of chondrichthyans and coelacanth (Amemiya et al., 2013; Renz et al., 2013; Venkatesh et al., 2014), element 1586 is conserved in tetrapods, coelacanth, and chondrichthyans, but not in gar, medaka, and zebrafish (Figure 3A). To assess whether the element 1586 in different species has different functionalities, we cloned this element from chick, S. canicula, and C. milii in front of a basal promoter followed by a GFP reporter (Ochi et al., 2012; Figure 3B). These constructs were electroporated into chick forelimb buds with a constitutively active RFP vector (to determine the spatial efficiency of electroporation). As with endogenous Gli3 expression (Büscher et alı, 1997), the chick element 1586 drove GFP expression specifically in anterior tissue and was repressed in the posterior region, even though RFP was expressed throughout the buds (Figure 3C). The element 1586 from both $S$. canicula and C. milii also drove GFP expression in the chick limb buds, confirming that its general activity is conserved from sharks to tetrapods. However, in both cases, the specific posterior repression observed in the chick element was absent (Figure 3D,E). Thus, the differential activity of this enhancer (with tetrapods showing posterior repression, and chondrichthyans not) recapitulates the differences in Gli3 expression within these groups. Furthermore, by recombining $S$. canicula and chick enhancers, we identified a sequence that can exert the posterior repression when inserted into the S. canicula enhancer (Figure 3F,G and Figure 3-figure 


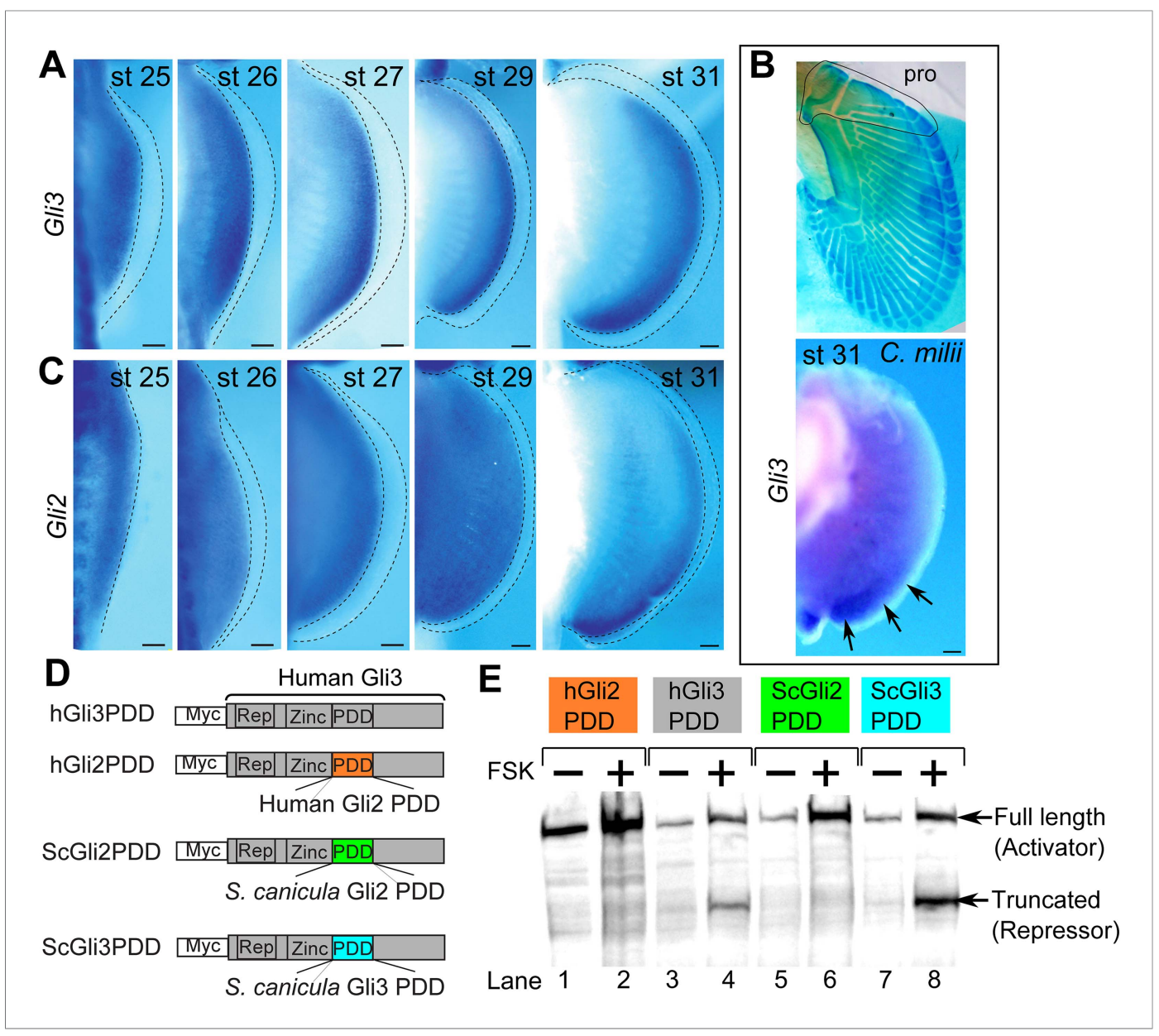

Figure 2. Expression and processing of Gli3 and Gli2 in S. canicula embryos. (A) Expression of Gli3 in S. canicula pectoral fins. (B) Alcian blue staining of $C$. milii pectoral fin at stage 35 (top, the ventral view of a right fin flipped horizontally) and Gli3 expression at stage 31 (bottom, a left pectoral fin flipped horizontally). pro, propterygium. (C) Expression of Gli2 in S. canicula pectoral fin buds. Scale bars, $100 \mu \mathrm{m}$. (D) The Gli3 chimera constructs. hGli3 PDD, full-length human Gli3 (grey box) with Myc tags. hGli2, ScGli2 and ScGli3 PDD, chimeric Gli3 genes recombined at the processing determinant domain (PDD) with human Gli2, S. canicula Gli2 and Gli3, respectively. (E) Protein processing of the chimeric constructs in cell cultures treated with either FSK (+) or DMSO (-). Truncated Gli3 is detected only in hGli3 PDD (lane 4) and ScGli3 PDD (lane 8).

DOI: 10.7554/eLife.07048.007

The following figure supplement is available for figure 2

Figure supplement 1. Phylogenetic tree of Gli2 and Gli3, and PDD amino acid sequences. DOI: 10.7554/eLife.07048.008

supplement 1). This sequence contains tetrapod or sarcopterygian-specific sequences, suggesting that the posterior repressive activity would have been acquired in a stepwise fashion.

Finally, we wished to address whether changes to AP positional information could modify skeletal arrangement of the propterygium and mesopterygium in catshark. For this purpose, we explored methodologies for performing manipulative experiments on this very slow-developing non-model fish (see 'Materials and methods'). We treated S. canicula embryos with retinoic acid (RA) to increase Shhsignalling activity (at stage 29 with $1 \mu \mathrm{g} / \mathrm{ml}$ of RA for 4 days). Activation of Shh signalling by RA is known to be conserved among vertebrate limbs/fins (Riddle et al., 1993; Hoffman et al., 2002; Dahn et al., 2007), and as expected, the most reliable Shh target gene, Ptch1 expression (Marigo et al., 1996; Vokes et al., 2008; and see Figure 1-figure supplement $1 F$ for phylogenetic analysis) was increased and expanded anteriorly (Figure 4A). Consistent with this, Hand2 expression also extended anteriorly (Figure 4B)—probably due to inhibition of Gli3 repressor formation by ectopic activation of 


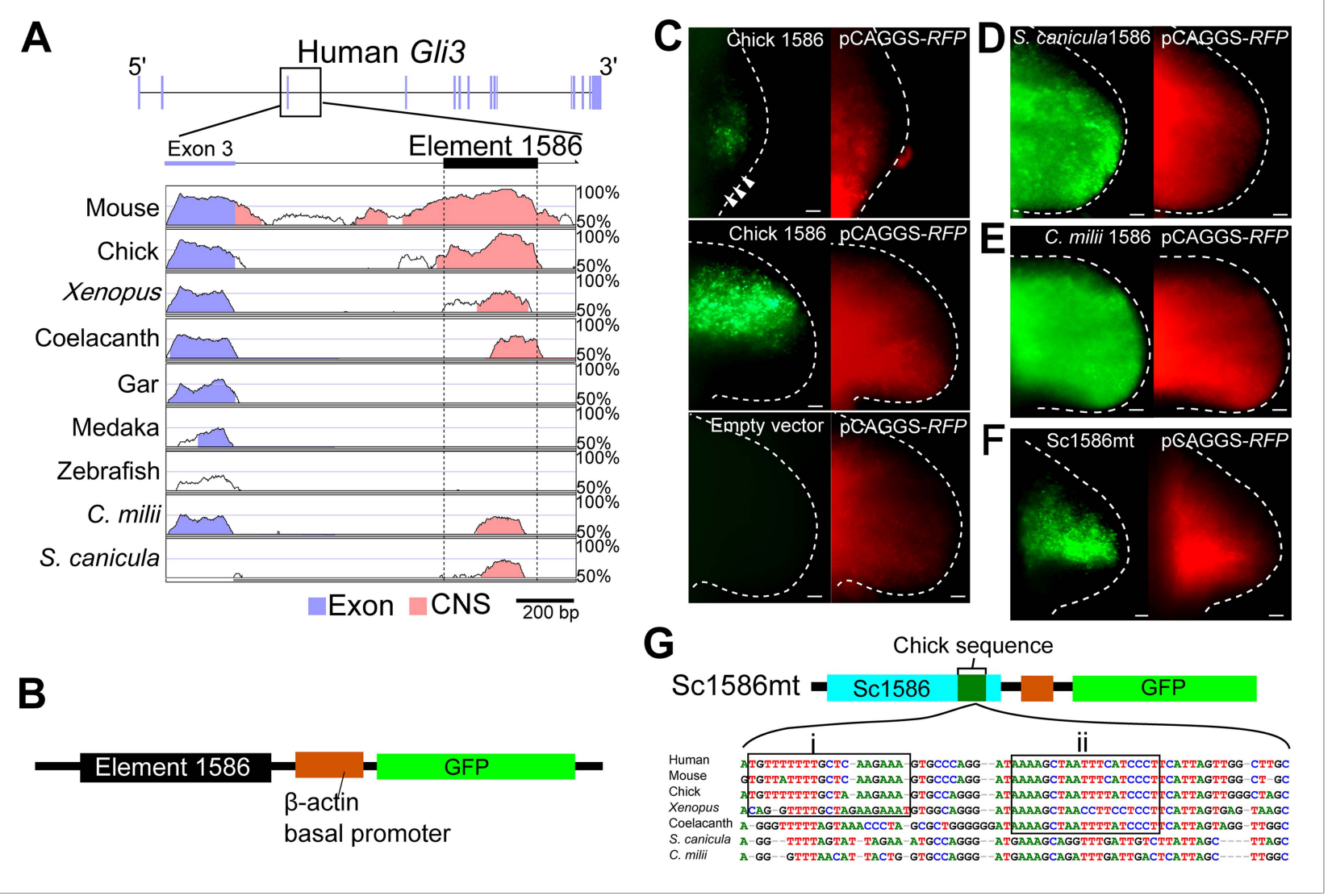

Figure 3. The Gli3 limb-specific enhancer of S. canicula and C. milii. (A) VISTA plots of Gli3 intron 3 from indicated animals. Blue vertical bars, exons of human Gli3; black rectangle, element 1586. Regions with $>70 \%$ identity are indicated: blue, exon; pink, non-coding sequences. (B) The enhancer construct. (C) GFP expression in chick forelimb buds driven by chick element 1586 at stage 19 (top, $n=3 / 3$ ), stage 23 (middle, $n=14 / 14$ ), and empty vector (bottom, $n=0 / 7)$. pCAGGS-RFP (right). (D-F) GFP expression driven by element 1586 of S. canicula $(\mathbf{D}, n=11 / 11), C$. milii $(\mathbf{E}, n=10 / 10)$ and Sc1586mt (F,n = 4/4). Scale bars, $100 \mu \mathrm{m}$. (G) Scheme of Sc1586mt, S. canicula enhancer (blue) partially replaced by chick sequence (green) and alignment. Boxes indicate tetrapod (i) and sarcopterygian (ii) specific sequences.

DOI: 10.7554/eLife.07048.009

The following figure supplement is available for figure 3 :

Figure supplement 1. Detailed functional analyses of element 1586.

DOI: 10.7554/eLife.07048.010

Shh signalling (as revealed by the extended Ptch1 expression). On the other hand, Pax9 expression (an anterior marker) was significantly downregulated and showed only weak expression in the anterior part of the fin buds (Figure 4C). The most anterior regions may not be sensitive to this treatment, as expression of Alx4 was not significantly shifted (Figure 4D), and this may be due to the lack of inhibitory regulation from Hand2 to Gli3 described above. To test whether the results of RA treatment were due to specific effects on AP patterning or instead due to a more general interference with limb development, we examined a marker for proximal-distal (PD) patterning in mouse and chick limb buds-Hoxa13 (Tamura et al., 1997; Mercader et al., 2000; Yashiro et al., 2004). In RA-treated pectoral fin buds, Hoxa13 expression was weaker than in control, but a shift in its expression domain was not seen (Figure 4E), showing that the impact of RA in these experiments is primarily on the AP patterning (the shifts of Ptch1, Hand2, and Pax9, Figure 4A-C), rather than on PD patterning or a general impact on development. Most intriguingly, we examined skeletal patterns of $S$. canicula pectoral fins in these partially 'posteriorised' fin buds (Figure 4F). Phenotypes varied from mild to severe but in all cases the appearance of distinct anterior elements (propterygium and mesopterygium) was lost. In the mild cases, a proximal element anterior to the metapterygium is attached to the pectoral girdle (single asterisk in Figure 4F). This proximal element may result from 


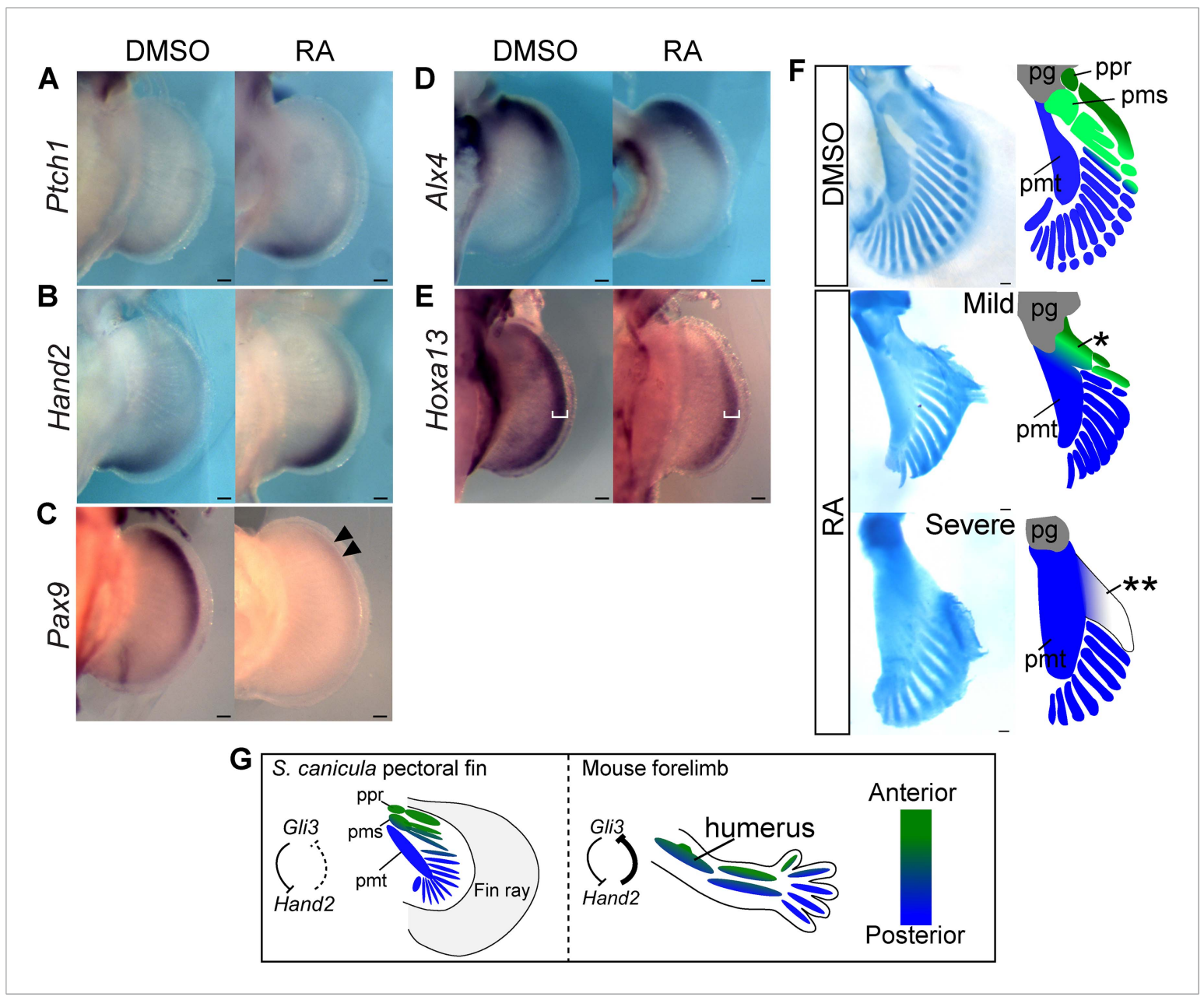

Figure 4. RA treatment causes ectopic activation of Shh signalling and loss of anterior skeletal elements. (A-E) In situ hybridisation of S. canicula pectoral fin buds for Ptch1 (A; left fins flipped horizontally), Hand2 (B), Pax9 (C), Alx4 (D), and Hoxa13 (E) treated with $1 \%$ DMSO or $1 \mu \mathrm{g} / \mathrm{ml}$ retinoic acid (RA) ( $n=2 / 2$ for each for each except $n=4 / 4$ for Hand2). Arrowheads in C, a weak expression of Pax9. White brackets in $\mathbf{E}$, width of Hoxa13 expression domain along the proximal-distal (PD) axis. (F) Pectoral fin skeletal patterns of 1\% DMSO control $(n=4)$ and $1-2 \mu \mathrm{g} / \mathrm{ml}$ RA ( $n=4)$. Right panels, schematics of interpretive skeletal patterns. *, an anterior proximal radial; ${ }^{* *}$, a fused radial attached to the metapterygium; pg, pectoral girdle; ppr, pms and pmt, proximal propterygium, mesopterygium and metapterygium. Scale bars, $100 \mu \mathrm{m}$. (G) Comparison between $\mathrm{S}$. canicula fin and mouse limb. Green and blue colours represent anterior-posterior (AP) positional information. ppr, pms, and pmt denote proximal propterygium, mesopterygium, and metapterygium, respectively. DOI: 10.7554/eLife.07048.011

a fusion of the proximal parts of propterygium and mesopterygium. Whereas, the severe cases still have a fused element anterior to the metapterygial axis (double asterisk in Figure 4F), but this element is not directly attached to the pectoral girdle, indicating that the pectoral fin of the severe phenotype has lost the anterior proximal elements. By contrast, the posterior metapterygium itself was larger than normal, but retained its strong identity as the primary axis from which radial branching was observed. Although RA treatment potentially cause non-specific effects, given the clear affect on AP patterning (the shifts of Ptch1, Hand2, and Pax9, Figure 4A-C), while causing no obvious effects on PD patterning, the main cause of the phenotype is likely caused by the AP pattern change.

In the present study, we have found that $S$. canicula pectoral fin buds have a gross posterior shift in the AP coordinate system compared to mouse limb buds. We show that $S$. canicula and $C$. milii lack a specific enhancer activity for Gli3, which in tetrapods mediates the posterior repression, and that this genetic difference likely contributes to the shift of AP positional information. Finally, RA treatment analyses suggest that a partial posteriorisation of $S$. canicula fin buds leads to a loss of anterior proximal elements (propterygium and mesopterygium). Thus, while the loss of the anterior proximal 
elements during evolution was associated with cis-regulatory changes of Gli3 in the RA experiments, it was driven by a Shh-mediated affect on the Gli3 protein itself, but in both cases achieving similar phenotypic changes by anterior shift in AP pattern. In support of our observations, a recent study also showed that anterior extension of Shh signalling accompanied with an anterior shift of Gli3 expression resulted in a loss of anterior skeletal elements in mouse limbs (Li et al., 2014). Considering all these data together, we therefore propose that one of the key events during the fin-to-limb transition was an anterior shift of AP positional information (a posteriorisation), which caused the loss of anterior proximal elements (Figure $4 G$ ).

In the RA treatment experiments, we also observed that the anterior distal radials reduced and only metapterygial radials retained, suggesting that anterior shift in AP positional information may also have had an impact on the distal radials during the fin-to-limb transformation. Interestingly, nearly 30 years ago, a classic study proposed that the distal end of the metapterygial axis (which has a uniformly posterior position in chondrychthians) bent anteriorly during acquisition of digits-the so-called digital arch model (Shubin and Alberch, 1986; Oster et al., 1988). Although the detailed validity of this model is unclear (Wagner and Larsson, 2007), there is a possibility that an AP shift in molecular patterning was involved in the acquisition of digits. In addition to our RA treatment analysis, knockdown analyses of actinotrichia proteins, which are components of fin rays and lost in tetrapod, show an anterior shift in several gene expressions in zebrafish pectoral fin buds (Zhang et al., 2010). Therefore, it is interesting to speculate that AP positional information may have shifted several times until the acquisition of digits.

We have shown that the Gli3 regulatory region of $S$. canicula and $C$. milii lacks the tetrapod-specific repressive element, which is likely needed for the Gli3-Hand2 interaction in mouse limb buds. In mice, $\mathrm{Gli3}^{-1-}$; Hand2-/c limbs show a severe dysplastic humerus (some of them have ectopic protrusion in humerus; Osterwalder et al., 2014), suggesting that the Gli3-Hand2 interaction has an important role for patterning the proximal elements. However, how Gli3 regulates the proximal skeletal pattern is not well understood even in mice. Although Gli3 is involved in the stylopod (humerus/femur) formation in mice, the phenotype in stylopod always appears with combination of other gene knockouts. For example, Gli3 ${ }^{-1-} ; \mathrm{Plzf}^{-1-}$ mice lack a femur, and $\mathrm{Gli3}^{-1-} ; \mathrm{Al} \times \mathrm{x}^{-1-}$ mice exhibit humerus malformation (Barna et al., 2005; Panman et al., 2005). These facts suggest that evolutionary modification of Gli3 regulation is likely necessary, but additional regulatory modifications are required for the loss of the anterior elements. Since $A l \times 4$ and Hand2 are expressed in $S$. canicula pectoral fin bud, and Plzf is involved only in hindlimb development, currently there is no obvious candidate that would be involved in the loss of propterygium and mesopterygium. Although S. cacnicula genome has not been sequenced, systematic studies at genome-wide level such as ChIP-seq in S. cacnicula pectoral fin buds would be invaluable to provide a more complete picture of evolutionary mechanism of the loss of the anterior elements in the future.

In conclusion, by taking advantage of the slow evolutionary rates of chondrichthyian genomes, we were able to precisely compare the gene expression, function and regulation between pectoral fin and limb development, and discover a key difference between them. In particular, our study suggest that changes in morphogen interpretation by gene regulatory network mutations may have a major impact on morphological evolution.

\section{Materials and methods}

\section{Animals}

Experiments were performed in accordance with guidelines for animal experiments of Tokyo Tech and CRG, and experiments involved in mice were approved by animal ethics committees of CRG (JMC-071001P3-JS). Catshark (S. canicula) eggs were incubated at $12-16^{\circ} \mathrm{C}$ in seawater and staged according to (Ballard et al., 1993). C. milii eggs and embryos were collected as described (Takagi et al., 2012) and staged according to (Didier et al., 1998). C52BL/6 (Charles River Laboratories, Wilmington, MA) mouse timed-pregnant females were sacrificed at different days after gestation E11.5. Chicken (Gallus gallus) eggs were incubated at $38^{\circ} \mathrm{C}$ in a humidified incubator until the desired Hamburger-Hamilton $(\mathrm{HH})$ stage (Hamburger and Hamilton, 1951) was reached. For in situ hybridisation, embryos were fixed overnight in $4 \%$ paraformaldehyde in phosphate-buffered saline, dehydrated in a graded methanol series, and stored in $100 \%$ methanol at $-20^{\circ} \mathrm{C}$. 


\section{Gene isolation and phylogenetic analysis}

Total RNA was extracted from stage 24 to 29 S. canicula embryos, stage 28 chick embryos and E11.5 mouse embryos using an RNeasy kit (Qiagen, Netherlands). cDNA was synthesised by reverse transcription and used as a template for PCR. Extraction of total RNA and cDNA synthesis from C. milii embryos were carried out as described (Takagi et al., 2012). To clone S. canicula and C. milii genes, we used primers that were based on the nucleotide sequences of putative $C$. milii orthologues found in the Elephant Shark Genome Project database (http://esharkgenome.imcb.a-star.edu.sg/) (Venkatesh et al., 2007) for Pax9, Alx4, and Gli3; SkateBase (http://skatebase.org/) (Wang et al., 2012) for Hand1, Zic3, Tbx2, and Ptch1; and GenBank for Gli2 (EU196410) and Sox9 (EU241880): S. canicula Alx4, 5'-AGGAATGAACGGCGAGACTTG-3' and 5'-TCATGTTGCCCAAGATATAGC-3'; S. canicula Pax9, 5'-GCTGTGTCAGCAAGATACTGG-3' and 5'-CCGCACTGTATGTCATGTAGG-3'; S. canicula Gli3, 5'-CAGCCCAGCAGAATACTACC-3' and 5'-GAGATCTCAGCGCCATTGATG-3'; S. canicula Gli2, 5'-GTAAAGCTTACTCACGACTCG-3' and 5'-CGTAAGAGTCAGCCGAGCTGATG-3'; S. canicula Sox9, 5'-CCCAGGTGCTGAAGGGATAC-3' and 5'-GGCAGGTACTGGTCGAACTC-3'; S. canicula Hand1, 5'-GAGAGCATCAACAGCGCATTCGC-3' and 5'-TTCCTGGTCCTCAACCTGGTC AG-3'; S. canicula Zic3, 5'-GTGGCCATGGCGATGTTACTGGATGGTG-3' and 5'-GTTTCTCGCCGGTG TGCACTCGGATGTG-3'; S. canicula Tbx2， 5'-GACACAGAAACCAGCTTCAGTCACAGTC-3' and 5'-GAAAGTCGCGATACCCAATGTGGATCAG-3'; S. canicula Ptch1, 5'-GAGGTTTCACCTCTCGAT GGGAGAACC-3' and 5'-CCATACTAATGTGTTCTGTTCCCACTG-3'; C. milii Gli3, 5'-GAGATCTC AGCGCCATTGATG-3' and 5'-GAGATCTCAGCGCCATTGATG-3'. To clone chick and mouse genes, we used primers that were based on the nucleotide sequences of Pax9 (NM_204912) (Muller et alo, 1996), Hoxa13 (NM_204139), and Tbx2 (NM_009324) (Bollag et alo, 1994a): chick Pax9, 5'-TGAGCGA CACCTCGTCGTACC-3' and 5'-GGTTATGCGATCCACTGCTA-3'; chick Hoxa13, 5'-GTCATGTTCCTC TACGACAAC-3' and 5'-GGTGGACTTCCAGAGGTGAGG-3'; mouse Tbx2, 5'-ATCCTGAACTCCAT GCACAAGTACC-3' and 5'-GAACTGCTGCCCATGCAGGTGGCTG-3'. The gene fragments were cloned into pBluescript SK- or pCR4 (Invitrogen, Thermo Fisher Scientific Inc., Waltham, MA). The partial coding sequences for Alx4 (1112 bp), Pax9 (729 bp), Gli3 (1937 bp), Hand1 (465 bp), Tbx2 (926 bp), Zic3 (919 bp) and Ptch1 (791 bp) of S. canicula and Gli3 (428 bp) of C. milii have been submitted to GenBank under accession numbers KC507187-9, KF748129, and KP055651-KP055653, KF297620, respectively. Phylogenetic analysis was used to confirm the orthology of newly identified $S$. canicula and $C$. milii genes. Amino acid sequences were aligned using ClustalX (Thompson et al., 1997). Regions that could not be aligned were excluded from the analysis. Neighbour-joining phylogenetic trees of amino acid sequence data sets were constructed with MEGA5 (Tamura et al., 2011). Bootstrapping was carried out with 1000 replicates.

\section{Probe synthesis and in situ hybridisation}

Chick Alx4 (NM_204162) was kindly provided by Dr Toshihiko Ogura. Riboprobes for Hand2 (AY057890) and Hoxa13 (EU005550) of S. canicula and for chick Alx4 were synthesised as described (Takahashi et al., 1998; Tanaka et al., 2002a; Sakamoto et al., 2009a). The cloned genes described above were used as templates for riboprobe synthesis. Whole-mount in situ hybridisation was carried out as described (Tanaka et al., 2002a). Sox9 expressions were scanned with Optical Projection Tomography (OPT) as described (Sharpe et al., 2002) and analysed with Volviewer (Lee et al., 2006).

\section{Gli processing analysis}

Human Gli3 (clone name: pFN21AE1055) and Gli2 (Roessler et al., 2005) were obtained from the Kazusa DNA Research Institute (Nagase et al., 2008) and Addgene, respectively. pCAGGS was kindly provided by Dr Toshihiko Ogura and originated from Dr Jun-ichi Miyazaki (Niwa et al., 1991). For Western blotting analysis, the N-terminal HaloTag in the human Gli3 construct was replaced with a 6xMyc tag (Myc-hsGli3). Then, the human Gli3 PDD (amino acids 644-842) (Pan and Wang, 2007) was replaced with the homologous domain from human Gli2 and S. canicula Gli2 and Gli3 by a combination of PCR (Wurch et al., 1998) and restriction enzyme digestions. The HEK293 cell line was kindly provided by Dr Masayuki Komada. HEK293 cells were grown in Dulbecco's modified Eagle medium (Sigma-Aldrich, St. Louis, MO) supplemented with 10\% foetal bovine serum (Gibco, Thermo Fisher Scientific Inc., Waltham, MA) and penicillin/streptomycin (Sigma-Aldrich) at $37^{\circ} \mathrm{C}$. For Western blot analysis, cells were plated in 6-well plates without penicillin/streptomycin and transfected with $4 \mu \mathrm{g}$ of constructs using polyethylenimine (GE Healthcare, England) for $3 \mathrm{hr}$. After the transfection, the medium was changed, and cells were cultured for 
$24 \mathrm{hr}$ and then treated with $50 \mu \mathrm{M}$ forskolin (FSK; Sigma) in Dimethyl sulfoxide (DMSO) DMSO or with DMSO alone for $24 \mathrm{hr}$. Whole-cell extracts were prepared by solubilisation in lysis buffer containing 50 $\mathrm{mM}$ Tris- $\mathrm{HCl}, \mathrm{pH} 7.5 ; 150 \mathrm{mM} \mathrm{NaCl} ; 1 \mathrm{mM}$ ethylenediaminetetraacetic acid (EDTA); 1\% Triton X-100; $0.1 \%$ Sodium Dodecyl Sulfate (SDS)S; $1 \%$ sodium deoxycholate; and protease inhibitor cocktail (Roche, Switzerland). Whole-cell lysates were separated by sodium dodecyl sulphate-polyacrylamide gel electrophoresis and analysed by Western blotting and anti-c-Myc (Sigma-Aldrich), anti-rabbit IgG secondary antibody conjugated with horseradish peroxidase (Jackson ImmunoResearch, West Grove, PA), and enhanced chemiluminescence detection (GE Healthcare).

\section{Enhancer analysis}

The limb-specific Gli3 enhancer was found with VISTA enhancer browser (http://enhancer.lbl.gov/) (Visel et al,, 2007). The enhancer ID is hs1586, which is located in Gli3 intron 3 in the human genome (hg19). For alignment, Gli3 intron 3 sequences from mouse (Mus musculus), chick (G. gallus), frog (Xenopus tropicalis), coelacanth (Latimeria chalumnae), gar (Lepisosteus oculatus), medaka (Oryzias latipes), and zebrafish (Danio rerio) from the Ensembl and Pre Ensembl genome browsers (http://www.ensembl.org/, http://pre.ensembl.org/) were collected. The element 1586 homologue from elephant shark (C. milii) was retrieved from the genome assembly (http://esharkgenome.imcb.a-star.edu.sg/) (Venkatesh et al., 2007) by using human element 1586 sequence as the query. The GenBank accession number of the $C$. milii element 1586 is AAVX01295166. The S. canicula counterpart of element 1586 was amplified by PCR with primers designed from conserved sequences of the upstream exon and the distal part of element 1586: 5'-AGTGGACCCCCGAAATGGCTACATGGACC-3' and 5'-GAACATCTTCTAATTTACTGGAATCCCAG-3. The amplified fragment was then cloned into pBluescript SK-. The sequence of $S$. canicula element 1586 was deposited in GenBank under accession number KF297619. The alignment was carried out with the SLAGAN method, and overall sequence similarities in the alignment were visualised with mVISTA (Mayor et al., 2000; Brudno et al., 2003; Frazer et al., 2004).

For functional analysis, the element 1586 homologues were isolated from chick and C. milii genomes by PCR. The following forward and reverse primers were used: chick element 1586 , 5'-CGAGCTCCCTCCTCAGTCATTCAGTTCTGC-3' and 5'-TGTGTGAGACATACTTTGATC-3'; C. milii element 1586, 5'-GAGCTCGTACAGTGATGACTGAAATGGTG-3' and 5'-GAGATTTCGAGTCTCTTT GATC-3'. The amplified DNA fragments were cloned into pBluescript SK-. To subclone the $S$. canicula 1586 fragment, we used the following primers: 5'-CCGCTCTAGAACTAGCATCAATATGATTTGCT GAG-3' and 5'-CGGGGGATCCACTAG GCTTCACGAGCATCAGGAAC-3'. The element 1586 sequence from each species was subcloned in front of a chicken $\beta$-actin basal promoter that is followed by a GFP reporter (Ochi et al., 2012). Recombined enhancers were created by PCR. In ovo, electroporation was carried out as described (Suzuki and Ogura, 2008). A DNA solution was prepared with Maxi Prep (Qiagen). pCAGGS-RFP was kindly provided by Dr Cheryll Tickle. Gli3 limb enhancers and empty $\beta$-actin basal promoter-GFP at $\sim 6 \mu \mathrm{g} / \mu \mathrm{l}$, coloured with $\sim 3 \%$ fast green, and co-electroporated with pCAGGS-RFP $(\sim 2 \mu \mathrm{g} / \mu \mathrm{l})$ into the presumptive forelimb field of stage 13-14 embryos. A CUY21EDIT II electroporator (BEX Co., Ltd., Japan) was used. Electric pulses consisted of one short pulse ( $25 \mathrm{~V}, 0.05 \mathrm{~ms})$ and a 0.1 -ms interval, followed by five long pulses (8 V, $10 \mathrm{~ms})$ with 1 $\mathrm{ms}$ intervals. The electric pulses were applied during injection of the DNA solution.

\section{RA treatment}

S. canicula embryos were removed from their egg shells, then placed into 6-well plates. 4-6 $\mathrm{ml}$ of artificial seawater containing penicillin/streptomycin was used for culturing embryos. RA was dissolved in DMSO to $2 \mathrm{mg} / \mathrm{ml}$ as a stock solution and diluted in the artificial seawater to $1-2 \mu \mathrm{g} / \mathrm{ml} .1 \%$ DMSO in the artificial seawater was used as negative controls. Embryos at stage 28-29 were cultured with RA for 4 days for gene expression analyses. For alcian blue staining, embryos at stage $28-29$ were cultured with $1-2 \mu \mathrm{g} / \mathrm{ml}$ RA for 20 days and additional 10-18 days after removing RA. Note that effect of RA is highly dependent on individual embryos. Some batches of embryos were lethal at $2 \mu \mathrm{g} / \mathrm{ml}$ of RA, probably due to season or parents' condition. In this case, embryos were treated with $1 \mu \mathrm{g} / \mathrm{ml}$ of RA.

\section{Acknowledgements}

We thank T Ogura, J Miyazaki, A Kuroiwa, H Ogino, and H Ochi for providing the plasmids; A Tweedale and Station Biologique de Roscoff for collecting S. canicula embryos; JA Donald, T Toop, and JD Bell for collecting C. milii embryos; M Komada for providing cell lines; M Davy, XXu, S Kuratani, and C 
Tickle for comments; and K Munakata, S Ueda, and N Suda for technical advice. Sequences for Alx4, Pax9, Gli3, Hand1, Tbx2, Zic3, Ptch1, and element 1586 from S. canicula and Gli3 from C. milii are deposited in GenBank under accession numbers KC507187-9, KF748129, KP055651-KP055653, KF297619, and KF297620. Correspondence and requests for materials should be addressed to M Tanaka (mitanaka@bio. titech.ac.jp) and J Sharpe (james.sharpe@crg.eu). This work was supported in part by the Global COE Program 'Evolving Education and Research Center for Spatio-Temporal Biological Network' from the Ministry of Education, Culture, Sports, Science and Technology (MEXT) to KO and MT, the Japan-Australia Research Cooperative Program to SH, the Grant-in-Aid for Scientific Research on Innovative Areas, the Grant-in-Aid for Scientific Research (B) and the Inamori Foundation to MT, ICREA and the Spanish Ministry of Economy and Competitiveness, 'Centro de Excelencia Severo Ochoa 20132017', SEV-2012-0208 to JS and the Centre for Genomic Regulation to KO and JS.

\section{Additional information}

Funding

\begin{tabular}{|c|c|c|}
\hline Funder & Grant reference & Author \\
\hline $\begin{array}{l}\text { Japan Society for the Promotion } \\
\text { of Science (JSPS) }\end{array}$ & $\begin{array}{l}\text { Grant-in-Aid for Scientific } \\
\text { Research (B) }\end{array}$ & Mikiko Tanaka \\
\hline $\begin{array}{l}\text { Ministry of Education, Culture, } \\
\text { Sports, Science, and Technology } \\
\text { (MEXT) }\end{array}$ & $\begin{array}{l}\text { Grant-in-Aid for Scientific } \\
\text { Research on Innovative Areas }\end{array}$ & Mikiko Tanaka \\
\hline $\begin{array}{l}\text { Japan Society for the Promotion } \\
\text { of Science (JSPS) }\end{array}$ & $\begin{array}{l}\text { Japan-Australia Research } \\
\text { Cooperative Program }\end{array}$ & $\begin{array}{l}\text { Susumu } \\
\text { Hyodo }\end{array}$ \\
\hline $\begin{array}{l}\text { Spanish Ministry of Economy and } \\
\text { Competitiveness (MINECO) }\end{array}$ & $\begin{array}{l}\text { Plan Nacional Grant (BFU2010- } \\
\text { 16428) }\end{array}$ & James Sharpe \\
\hline
\end{tabular}

Author contributions

KO, Conception and design, Acquisition of data, Analysis and interpretation of data, Drafting or revising the article, Contributed unpublished essential data or reagents; SK, Acquisition of data, Analysis and interpretation of data, Contributed unpublished essential data or reagents; WT, SH, Acquisition of data, Contributed unpublished essential data or reagents; JS, MT, Conception and design, Analysis and interpretation of data, Drafting or revising the article

Ethics

Animal experimentation: Experiments were performed in accordance with guidelines for animal experiments of Tokyo Tech and CRG, and experiments involved in mice were approved by Animal Ethics Committees of CRS (No. JMC-07-1001P3-JS).

\section{Additional files}

Major datasets

The following datasets were generated:

\begin{tabular}{|c|c|c|c|c|}
\hline Author(s) & Year & Dataset title & $\begin{array}{l}\text { Dataset ID } \\
\text { and/or URL }\end{array}$ & $\begin{array}{l}\text { Database, license, and } \\
\text { accessibility information }\end{array}$ \\
\hline Onimaru K, Tanaka M & 2014 & $\begin{array}{l}\text { Scyliorhinus canicula Alx4 } \\
\text { mRNA, complete cds }\end{array}$ & $\begin{array}{l}\text { http://www.ncbi.nlm.nih. } \\
\text { gov/nuccore/KC507187 }\end{array}$ & $\begin{array}{l}\text { Publicly available at the } \\
\text { NCBI Nucleotide } \\
\text { (Accession no: } \\
\text { KC507187). }\end{array}$ \\
\hline Onimaru K, Tanaka M & 2014 & $\begin{array}{l}\text { Scyliorhinus canicula Pax9 } \\
\text { mRNA, partial cds }\end{array}$ & $\begin{array}{l}\text { http://www.ncbi.nlm.nih. } \\
\text { gov/nuccore/KC507188 }\end{array}$ & $\begin{array}{l}\text { Publicly available at the } \\
\text { NCBI Nucleotide } \\
\text { (Accession no: } \\
\text { KC507188). }\end{array}$ \\
\hline
\end{tabular}




\begin{tabular}{lll}
\hline Author(s) & Year & Dataset title \\
\hline Onimaru K, Tanaka M & $2014 \begin{array}{l}\text { Scyliorhinus canicula Gli3 } \\
\text { mRNA, partial cds }\end{array}$
\end{tabular}

Dataset ID

http://www.ncbi.nlm.nih gov/nuccore/KC507189 and/or URL

Database, license, and accessibility information

Publicly available at the $\mathrm{NCBI}$ Nucleotide (Accession no: KC507189).

\begin{tabular}{|c|c|c|c|c|}
\hline $\begin{array}{l}\text { Onimaru K, Kuraku S, } \\
\text { Takagi W, Hyodo S, } \\
\text { Tanaka M }\end{array}$ & 2014 & $\begin{array}{l}\text { Scyliorhinus canicula } \\
\text { element } 1586 \text {, genomic } \\
\text { sequence, a fin/limb } \\
\text { enhancer of Gli3 }\end{array}$ & $\begin{array}{l}\text { http://www.ncbi.nlm.nih. } \\
\text { gov/nuccore/KF297619 }\end{array}$ & $\begin{array}{l}\text { Publicly available at the } \\
\text { NCBI Nucleotide } \\
\text { (Accession no: KF297619). }\end{array}$ \\
\hline $\begin{array}{l}\text { Onimaru K, Kuraku S, } \\
\text { Takagi W, Hyodo S, } \\
\text { Tanaka M }\end{array}$ & 2014 & $\begin{array}{l}\text { Scyliorhinus canicula } \\
\text { Hand1 mRNA, partial cds }\end{array}$ & $\begin{array}{l}\text { http://www.ncbi.nlm.nih. } \\
\text { gov/nuccore/KF748129 }\end{array}$ & $\begin{array}{l}\text { Publicly available at the } \\
\text { NCBI Nucleotide } \\
\text { (Accession no: KF748129). }\end{array}$ \\
\hline $\begin{array}{l}\text { Onimaru K, Kuraku S, } \\
\text { Takagi W, Hyodo S, } \\
\text { Sharpe J, Tanaka M }\end{array}$ & 2015 & $\begin{array}{l}\text { S. canicula Zic3 mRNA, } \\
\text { partial cds }\end{array}$ & $\begin{array}{l}\text { http://www.ncbi.nlm.nih. } \\
\text { gov/nuccore/KP055652 }\end{array}$ & $\begin{array}{l}\text { Publicly available at the } \\
\text { NCBI Nucleotide } \\
\text { (Accession no: KP055652). }\end{array}$ \\
\hline $\begin{array}{l}\text { Onimaru K, Kuraku S, } \\
\text { Takagi W, Hyodo S, } \\
\text { Sharpe J, Tanaka M }\end{array}$ & 2015 & $\begin{array}{l}\text { S. canicula Tbx2 mRNA, } \\
\text { partial cds }\end{array}$ & $\begin{array}{l}\text { http://www.ncbi.nlm.nih. } \\
\text { gov/nuccore/KP055651 }\end{array}$ & $\begin{array}{l}\text { Publicly available at the } \\
\text { NCBI Nucleotide } \\
\text { (Accession no: KP055651). }\end{array}$ \\
\hline $\begin{array}{l}\text { Onimaru K, Kuraku S, } \\
\text { Takagi W, Hyodo S, } \\
\text { Sharpe J, Tanaka M }\end{array}$ & 2015 & $\begin{array}{l}\text { S. canicula Ptch1 mRNA, } \\
\text { partial cds }\end{array}$ & $\begin{array}{l}\text { http://www.ncbi.nlm.nih. } \\
\text { gov/nuccore/KP055653 }\end{array}$ & $\begin{array}{l}\text { Publicly available at the } \\
\text { NCBI Nucleotide } \\
\text { (Accession no: KP055653). }\end{array}$ \\
\hline $\begin{array}{l}\text { Onimaru K, Kuraku S, } \\
\text { Takagi W, Hyodo S, } \\
\text { Tanaka M }\end{array}$ & 2015 & $\begin{array}{l}\text { C. milii Gli3 mRNA, } \\
\text { partial cds }\end{array}$ & $\begin{array}{l}\text { http://www.ncbi.nlm.nih. } \\
\text { gov/nuccore/KF297620 }\end{array}$ & $\begin{array}{l}\text { Publicly available at the } \\
\text { NCBI Nucleotide } \\
\text { (Accession no: KF297620). }\end{array}$ \\
\hline \multicolumn{5}{|c|}{ The following previously published datasets were used: } \\
\hline Author(s) & Year & Dataset title & $\begin{array}{l}\text { Dataset ID } \\
\text { and/or URL }\end{array}$ & $\begin{array}{l}\text { Database, license, and } \\
\text { accessibility information }\end{array}$ \\
\hline $\begin{array}{l}\text { Tanaka M, Munsterberg } \\
\text { A, Anderson WG, } \\
\text { Prescott AR, Hazon N, } \\
\text { Tickle C }\end{array}$ & 2002 & $\begin{array}{l}\text { Scyliorhinus canicula } \\
\text { dHand protein mRNA, } \\
\text { partial cds }\end{array}$ & $\begin{array}{l}\text { http://www.ncbi.nlm.nih. } \\
\text { gov/nuccore/AY057890 }\end{array}$ & $\begin{array}{l}\text { Publicly available at the } \\
\text { NCBI Nucleotide } \\
\text { (Accession no: AY057890). }\end{array}$ \\
\hline $\begin{array}{l}\text { Sakamoto K, Onimaru K, } \\
\text { Munakata K, Suda N, } \\
\text { Tamura M, Ochi H, } \\
\text { Tanaka M }\end{array}$ & 2009 & $\begin{array}{l}\text { Scyliorhinus canicula } \\
\text { HoxA13 mRNA, } \\
\text { partial cds }\end{array}$ & $\begin{array}{l}\text { http://www.ncbi.nlm.nih. } \\
\text { gov/nuccore/EU005550 }\end{array}$ & $\begin{array}{l}\text { Publicly available at the } \\
\text { NCBI Nucleotide } \\
\text { (Accession no: EU005550). }\end{array}$ \\
\hline $\begin{array}{l}\text { Muller TS, Ebensperger } \\
\text { C, Neubuser A, Koseki H, } \\
\text { Balling R, Christ B, } \\
\text { Wilting J }\end{array}$ & 2015 & $\begin{array}{l}\text { Gallus gallus paired box } 9 \\
\text { (PAX9), mRNA }\end{array}$ & $\begin{array}{l}\text { http://www.ncbi.nlm.nih. } \\
\text { gov/nuccore/NM_204912 }\end{array}$ & $\begin{array}{l}\text { Publicly available at the } \\
\text { NCBI Nucleotide } \\
\text { (Accession no: } \\
\text { NM_204912). }\end{array}$ \\
\hline $\begin{array}{l}\text { Takahashi M, Tamura K, } \\
\text { Buscher D, Masuya H, } \\
\text { Yonei-Tamura S, } \\
\text { Matsumoto K, Naitoh- } \\
\text { Matsuo M, Takeuchi J, } \\
\text { Ogura K, Shiroishi T, } \\
\text { Ogura T, Izpisua } \\
\text { Belmonte JC }\end{array}$ & 2013 & $\begin{array}{l}\text { Gallus gallus ALX } \\
\text { homeobox } 4 \text { (ALX4), } \\
\text { mRNA }\end{array}$ & $\begin{array}{l}\text { http://www.ncbi.nlm.nih. } \\
\text { gov/nuccore/NM_204162 }\end{array}$ & $\begin{array}{l}\text { Publicly available at the } \\
\text { NCBI Nucleotide } \\
\text { (Accession no: } \\
\text { NM_204162). }\end{array}$ \\
\hline $\begin{array}{l}\text { Bollag RJ, Siegfried Z, } \\
\text { Cebra-Thomas J, Garvey } \\
\text { N, Davison EM, Silver LM }\end{array}$ & 1994 & $\begin{array}{l}\text { Mus musculus T-box } 2 \\
\text { (Tbx2), mRNA }\end{array}$ & $\begin{array}{l}\text { http://www.ncbi.nlm.nih. } \\
\text { gov/nuccore/120407038 }\end{array}$ & $\begin{array}{l}\text { Publicly available at the } \\
\text { NCBI Nucleotide } \\
\text { (Accession no: } \\
\text { NM_009324). }\end{array}$ \\
\hline Zhang G, Cohn MJ & 2009 & $\begin{array}{l}\text { Scyliorhinus canicula Sox9 } \\
\text { (Sox9) mRNA, } \\
\text { complete cds }\end{array}$ & $\begin{array}{l}\text { http://www.ncbi.nlm.nih. } \\
\text { gov/nuccore/EU241880 }\end{array}$ & $\begin{array}{l}\text { Publicly available at the } \\
\text { NCBI Nucleotide } \\
\text { (Accession no: EU241880). }\end{array}$ \\
\hline
\end{tabular}




\section{References}

Amemiya CT, Alföldi J, Lee AP, Fan S, Philippe H, Maccallum I, Braasch I, Manousaki T, Schneider I, Rohner N, Organ C, Chalopin D, Smith JJ, Robinson M, Dorrington RA, Gerdol M, Aken B, Biscotti MA, Barucca M, Baurain D, Berlin AM, Blatch GL, Buonocore F, Burmester T, Campbell MS, Canapa A, Cannon JP, Christoffels A, De Moro G, Edkins AL, Fan L, Fausto AM, Feiner N, Forconi M, Gamieldien J, Gnerre S, Gnirke A, Goldstone JV, Haerty W, Hahn ME, Hesse U, Hoffmann S, Johnson J, Karchner SI, Kuraku S, Lara M, Levin JZ, Litman GW, Mauceli E, Miyake T, Mueller MG, Nelson DR, Nitsche A, Olmo E, Ota T, Pallavicini A, Panji S, Picone B, Ponting CP, Prohaska SJ, Przybylski D, Saha NR, Ravi V, Ribeiro FJ, Sauka-Spengler T, Scapigliati G, Searle SM, Sharpe T, Simakov O, Stadler PF, Stegeman JJ, Sumiyama K, Tabbaa D, Tafer H, Turner-Maier J, van Heusden P, White S, Williams L, Yandell M, Brinkmann H, Volff JN, Tabin CJ, Shubin N, Schartl M, Jaffe DB, Postlethwait JH, Venkatesh B, Di Palma F, Lander ES, Meyer A, Lindblad-Toh K. 2013. The African coelacanth genome provides insights into tetrapod evolution. Nature 496:311-316. doi: 10.1038/nature12027.

Balaskas N, Ribeiro A, Panovska J, Dessaud E, Sasai N, Page KM, Briscoe J, Ribes V. 2012. Gene regulatory logic for reading the sonic hedgehog signaling gradient in the vertebrate neural tube. Cell 148:273-284. doi: 10.1016/ j.cell.2011.10.047.

Ballard WW, Mellinger J, Lechenault H. 1993. A series of normal stages for development of Scyliorhinus canicula, the lesser spotted dogfish (Chondrichthyes: Scyliorhinidae). Journal of Experimental Zoology 267:318-336. doi: 10.1002/jez.1402670309.

Barna M, Pandolfi PP, Niswander L. 2005. Gli3 and Plzf cooperate in proximal limb patterning at early stages of limb development. Nature 436:277-281. doi: 10.1038/nature03801.

Bollag RJ, Siegfried Z, Cebra-Thomas J, Garvey N, Davison EM, Silver LM. 1994a. An ancient family of embryonically expressed mouse genes sharing a conserved protein motif with the T-locus. Nature Genetics 7:383-389.

Bollag RJ, Siegfried Z, Cebra-Thomas J, Garvey N, Davison EM, Silver LM. 1994b. Mus musculus T-box 2 (Tbx2), mRNA. NCBI Nucleotide NM_009324. http://www.ncbi.nlm.nih.gov/nuccore/120407038.

Brudno M, Malde S, Poliakov A, Do CB, Couronne O, Dubchak I, Batzoglou S. 2003. Glocal alignment: finding rearrangements during alignment. Bioinformatics 19(Suppl 1):i54-i62. doi: 10.1093/bioinformatics/btg1005.

Büscher D, Bosse B, Heymer J, Rüther U. 1997. Evidence for genetic control of Sonic hedgehog by Gli3 in mouse limb development. Mechanisms of Development 62:175-182. doi: 10.1016/S0925-4773(97)00656-4.

Coates M. 2003. The evolution of paired fins. Theory in Biosciences 122:266-287. doi: 10.1007/s12064-003-0057-4. Coates M. 1994. The origin of vertebrate limbs. Development. Supplement 169-180.

Dahn RD, Davis MC, Pappano WN, Shubin NH. 2007. Sonic hedgehog function in chondrichthyan fins and the evolution of appendage patterning. Nature 445:311-314. doi: 10.1038/nature05436.

Davis MC, Dahn RD, Shubin NH. 2007. An autopodial-like pattern of Hox expression in the fins of a basal actinopterygian fish. Nature 447:473-476. doi: 10.1038/nature05838.

Didier DA, Leclair EE, Vanbuskirk DR. 1998. Embryonic staging and external features of development of the chimaeroid fish, Callorhinchus milii (Holocephali, Callorhinchidae). Journal of Morphology 236:25-47. doi: 10. 1002/(SICl)1097-4687(199804)236:1<25::AID-JMOR2>3.0.CO;2-N.

Fernandez-Teran M, Piedra ME, Rodriguez-Rey JC, Talamillo A, Ros MA. 2003. Expression and regulation of eHAND during limb development. Developmental Dynamics 226:690-701. doi: 10.1002/dvdy.10271.

Frazer KA, Pachter L, Poliakov A, Rubin EM, Dubchak I. 2004. VISTA: computational tools for comparative genomics. Nucleic Acids Research 32:W273-W279. doi: 10.1093/nar/gkh458.

Galli A, Robay D, Osterwalder M, Bao X, Bénazet J-D, Tariq M, Paro R, Mackem S, Zeller R. 2010. Distinct roles of Hand2 in initiating polarity and posterior Shh expression during the onset of mouse limb bud development. PLOS Genetics 6:e1000901. doi: 10.1371/journal.pgen.1000901.

Gegenbaur C. 1865. Untersuchungen zur vergleichenden anatomie der wirbeltiere. Vol. II: Wilhelm Engelmann. Leipzig. Hamburger V, Hamilton HL. 1951. A series of normal stages in the development of the chick embryo. Journal of Morphology 88:49-92. doi: 10.1002/aja.1001950404.

Hoffman L, Miles J, Avaron F, Laforest L, Akimenko MA. 2002. Exogenous retinoic acid induces a stage-specific, transient and progressive extension of Sonic hedgehog expression across the pectoral fin bud of zebrafish. The International Journal of Developmental Biology 46:949-956.

Lee K, Avondo J, Morrison H, Blot L, Stark M, Sharpe J, Bangham A, Coen E. 2006. Visualizing plant development and gene expression in three dimensions using optical projection tomography. The Plant Cell 18:2145-2156. doi: 10.1105/tpc.106.043042.

Li D, Sakuma R, Vakili NA, Mo R, Puviindran V, Deimling S, Zhang X, Hopyan S, Hui C. chung. 2014. Formation of proximal and anterior limb skeleton requires early function of Irx3 and Irx5 and is negatively regulated by shh signaling. Developmental Cell 29:233-240. doi: 10.1016/j.devcel.2014.03.001.

Marigo V, Scott MP, Johnson RL, Goodrich LV, Tabin CJ. 1996. Conservation in hedgehog signaling: induction of a chicken patched homolog by Sonic hedgehog in the developing limb. Development 122:1225-1233.

Maurya AK, Ben J, Zhao Z, Lee RT, Niah W, Ng AS, lyu A, Yu W, Elworthy S, van Eeden FJ, Ingham PW. 2013. Positive and negative regulation of gli activity by Kif7 in the zebrafish embryo. PLOS Genetics 9. doi: 10.1371/ journal.pgen.1003955.

Mayor C, Brudno M, Schwartz JR, Poliakov A, Rubin EM, Frazer KA, Pachter LS, Dubchak I. 2000. VISTA: visualizing global DNA sequence alignments of arbitrary length. Bioinformatics 16:1046-1047. doi: 10.1093/bioinformatics/16.11.1046.

McGlinn E, Van Bueren KL, Fiorenza S, Mo R, Poh AM, Forrest A, Soares MB, Bonaldo MDF, Grimmond S, Hui CC, Wainwright B, Wicking C. 2005. Pax9 and Jagged1 act downstream of Gli3 in vertebrate limb development. Mechanisms of Development 122:1218-1233. doi: 10.1016/j.mod.2005.06.012. 
Mercader N, Leonardo E, Piedra ME, Martínez AC, Ros MA, Torres M. 2000. Opposing RA and FGF signals control proximodistal vertebrate limb development through regulation of Meis genes. Development 127:3961-3970.

Muller TS, Ebensperger C, Neubuser A, Koseki H, Balling R, Christ B, Wilting J. 1996. Expression of avian Pax1 and Pax9 is intrinsically regulated in the pharyngeal endoderm, but depends on environmental influences in the paraxial mesoderm. Developmental Biology 178:403-417. doi: 10.1006/dbio.1996.0227.

Muller TS, Ebensperger C, Neubuser A, Koseki H, Balling R, Christ B, Wilting J. 2015. Gallus gallus paired box 9 (PAX9), mRNA. NCBI Nucleotide NM_204912. http://www.ncbi.nlm.nih.gov/nuccore/NM_204912.

Nagase T, Yamakawa H, Tadokoro S, Nakajima D, Inoue S, Yamaguchi K, Itokawa Y, Kikuno RF, Koga H, Ohara O. 2008. Exploration of human ORFeome: high-throughput preparation of ORF clones and efficient characterization of their protein products. DNA Research 15:137-149. doi: 10.1093/dnares/dsn004.

Niwa H, Yamamura K, Miyazaki J. 1991. Efficient selection for high-expression transfectants with a novel eukaryotic vector. Gene 108:193-199.

Ochi H, Tamai T, Nagano H, Kawaguchi A, Sudou N, Ogino H. 2012. Evolution of a tissue-specific silencer underlies divergence in the expression of pax2 and pax8 paralogues. Nature Communications 3:848. doi: 10.1038/ncomms1851.

Orvig T. 1962. Y a-t-il une relation directe entre les Arthrodires ptyctodontides et les Holocephales? In: Lehman JP, editor. Problèmes Actuels de Paléontologie. (Evolution des Vertébrés). Paris. Colloques Internationaux, 104. p. 49-61.

Oster GF, Shubin N, Murray JD, Alberch P. 1988. Evolution and morphogenetic rules: the shape of the vertebrate limb in ontogeny and phylogeny. Evolution 42:862-884. doi: 10.2307/2408905.

Osterwalder M, Speziale D, Shoukry M, Mohan R, Ivanek R, Kohler M, Beisel C, Wen X, Scales SJ, Christoffels VM, Visel A, Lopez-rios J, Zeller R. 2014. HAND2 targets define a network of transcriptional regulators that compartmentalize the early limb bud mesenchyme. Developmental Cell 31:345-357. doi: 10.1016/j.devcel.2014.09.018.

Pan Y, Wang B. 2007. A novel protein-processing domain in Gli2 and Gli3 differentially blocks complete protein degradation by the proteasome. The Journal of Biological Chemistry 282:10846-10852. doi: 10.1074/jbc. M608599200.

Panman L, Drenth T, Tewelscher P, Zuniga A, Zeller R. 2005. Genetic interaction of Gli3 and Alx4 during limb development. The International Journal of Developmental Biology 49:443-448. doi: 10.1387/ijdb.051984lp.

Renz AJ, Meyer A, Kuraku S. 2013. Revealing less derived nature of cartilaginous fish genomes with their evolutionary time scale inferred with nuclear genes. PLOS ONE 8:e66400. doi: 10.1371/journal.pone.0066400.

Riddle RD, Johnson RL, Laufer E, Tabin C. 1993. Sonic hedgehog mediates the polarizing activity of the ZPA. Cell 75:1401-1416. doi: 10.1016/0092-8674(93)90626-2.

Roessler E, Ermilov AN, Grange DK, Wang A, Grachtchouk M, Dlugosz AA, Muenke M. 2005. A previously unidentified amino-terminal domain regulates transcriptional activity of wild-type and disease-associated human GLI2. Human Molecular Genetics 14:2181-2188. doi: 10.1093/hmg/ddi222.

Sakamoto K, Onimaru K, Munakata K, Suda N, Tamura M, Ochi H, Tanaka M. 2009a. Heterochronic shift in Hoxmediated activation of Sonic hedgehog leads to morphological changes during fin development. PLOS ONE 4: e5121. doi: 10.1371/journal.pone.0005121.

Sakamoto K, Onimaru K, Munakata K, Suda N, Tamura M, Ochi H, Tanaka M. 2009b. Scyliorhinus canicula HoxA13 mRNA, partial cds. NCBI Nucleotide EU005550. http://www.ncbi.nlm.nih.gov/nuccore/EU005550.

Schweitzer R, Vogan KJ, Tabin CJ. 2000. Similar expression and regulation of Gli2 and Gli3 in the chick limb bud. Mechanisms of Development 98:171-174. doi: 10.1016/S0925-4773(00)00458-5.

Sharpe J, Ahlgren U, Perry P, Hill B, Ross A, Hecksher-Sørensen J, Baldock R, Davidson D. 2002. Optical projection tomography as a tool for 3D microscopy and gene expression studies. Science 296:541-545. doi: 10.1126/ science. 1068206.

Shubin NH, Alberch P. 1986. A morphogenetic approach to the origin and basic organization of the tetrapod limb. Evolutionary Biology 20:318-390.

Suzuki T, Ogura T. 2008. Congenic method in the chick limb buds by electroporation. Development, Growth \& Differentiation 50:459-465. doi: 10.1111/j.1440-169X.2008.01054.x.

Takagi W, Kajimura M, Bell JD, Toop T, Donald JA, Hyodo S. 2012. Hepatic and extrahepatic distribution of ornithine urea cycle enzymes in holocephalan elephant fish (Callorhinchus milii). Comparative Biochemistry and Physiology. Part B, Biochemistry \& Molecular Biology 161:331-340. doi: 10.1016/j.cbpb.2011.12.006.

Takahashi M, Tamura K, Buscher D, Masuya H, Yonei-Tamura S, Matsumoto K, Naitoh-Matsuo M, Takeuchi J, Ogura K, Shiroishi T, Ogura T, Belmonte JC. 1998. The role of Alx-4 in the establishment of anteroposterior polarity during vertebrate limb development. Development 125:4417-4425.

Takahashi M, Tamura K, Buscher D, Masuya H, Yonei-Tamura S, Matsumoto K, Naitoh-Matsuo M, Takeuchi J, Ogura K, Shiroishi T, Ogura T, Izpisua Belmonte JC. 2013. Gallus gallus ALX homeobox 4 (ALX4), mRNA. NCBI Nucleotide NM_204162. http://www.ncbi.nlm.nih.gov/nuccore/NM_204162.

Tamura K, Peterson D, Peterson N, Stecher G, Nei M, Kumar S. 2011. MEGA5: molecular evolutionary genetics analysis using maximum likelihood, evolutionary distance, and maximum parsimony methods. Molecular Biology and Evolution 28:1530-1534. doi: 10.1093/molbev/msr121.

Tamura K, Yokouchi Y, Kuroiwa A, Ide H. 1997. Retinoic acid changes the proximodistal developmental competence and affinity of distal cells in the developing chick limb bud. Developmental Biology 188:224-234. doi: $10.1006 /$ dbio.1997.8627.

Tanaka M, Münsterberg A, Anderson WG, Prescott AR, Hazon N, Tickle C. 2002a. Fin development in a cartilaginous fish and the origin of vertebrate limbs. Nature 416:527-531. doi: 10.1038/416527a.

Tanaka M, Munsterberg A, Anderson WG, Prescott AR, Hazon N, Tickle C. 2002b. Scyliorhinus canicula dHand protein mRNA, partial cds. NCBI Nucleotide AY057890. http://www.ncbi.nlm.nih.gov/nuccore/ AY057890. 
Te Welscher P, Fernandez-Teran M, Ros MA, Zeller R. 2002. Mutual genetic antagonism involving GLI3 and dHAND prepatterns the vertebrate limb bud mesenchyme prior to SHH signaling. Genes \& Development 16: 421-426. doi: 10.1101/gad.219202.

Thompson JD, Gibson TJ, Plewniak F, Jeanmougin F, Higgins DG. 1997. The CLUSTAL_X windows interface: flexible strategies for multiple sequence alignment aided by quality analysis tools. Nucleic Acids Research 25: 4876-4882. doi: 10.1093/nar/25.24.4876.

Venkatesh B, Kirkness EF, Loh Y-H, Halpern AL, Lee AP, Johnson J, Dandona N, Viswanathan LD, Tay A, Venter JC, Strausberg RL, Brenner S. 2007. Survey sequencing and comparative analysis of the elephant shark (Callorhinchus milii) genome. PLOS Biology 5:e101. doi: 10.1371/journal.pbio.0050101.

Venkatesh B, Lee AP, Ravi V, Maurya AK, Lian MM, Swann JB, Ohta Y, Flajnik MF, Sutoh Y, Kasahara M, Hoon S, Gangu V, Roy SW, Irimia M, Korzh V, Kondrychyn I, Lim ZW, Tay B-H, Tohari S, Kong KW, Ho S, Lorente-Galdos B, Quilez J, Marques-Bonet T, Raney BJ, Ingham PW, Tay A, Hillier LW, Minx P, Boehm T, Wilson RK, Brenner S, Warren WC. 2014. Elephant shark genome provides unique insights into gnathostome evolution. Nature $\mathbf{5 0 5}$ : 174-179. doi: 10.1038/nature12826.

Visel A, Minovitsky S, Dubchak I, Pennacchio LA. 2007. VISTA Enhancer Browser-a database of tissue-specific human enhancers. Nucleic Acids Research 35:D88-D92. doi: 10.1093/nar/gkl822.

Vokes SA, Ji H, Wong WH, McMahon AP. 2008. A genome-scale analysis of the cis-regulatory circuitry underlying sonic hedgehog-mediated patterning of the mammalian limb. Genes \& Development 22:2651-2663. doi: 10. 1101/gad.1693008.

Wagner GP, Larsson HCE. 2007. Fins into limbs: evolution, development, and transformation. In: Hall BK, editor. Fins and limbs in the study of evolutionary novelties: The University of Chicago Press. p. 49-61.

Wang B, Fallon J, Beachy P. 2000. Hedgehog-regulated processing of Gli3 produces an anterior/posterior repressor gradient in the developing vertebrate limb. Cell 100:423-434. doi: 10.1016/S0092-8674(00)80678-9.

Wang Q, Arighi CN, King BL, Polson SW, Vincent J, Chen C, Huang H, Kingham BF, Page ST, Farnum Rendino M, Thomas WK, Udwary DW, Wu CH. 2012. Community annotation and bioinformatics workforce development in concert-Little Skate Genome Annotation Workshops and Jamborees. Database 2012, bar064.

Wurch T, Lestienne F, Pauwels PJ. 1998. A modified overlap extension PCR method to create chimeric genes in the absence of restriction enzymes. Biotechnology Techniques 12:653-657. doi: 10.1023/A:1008848517221.

Yashiro K, Zhao X, Uehara M, Yamashita K, Nishijima M, Nishino J, Saijoh Y, Sakai Y, Hamada H. 2004. Regulation of retinoic acid distribution is required for proximodistal patterning and outgrowth of the developing mouse limb. Developmental Cell 6:411-422. doi: 10.1016/S1534-5807(04)00062-0.

Yokoyama S, Ito Y, Ueno-Kudoh H, Shimizu H, Uchibe K, Albini S, Mitsuoka K, Miyaki S, Kiso M, Nagai A, Hikata T, Osada T, Fukuda N, Yamashita S, Harada D, Mezzano V, Kasai M, Puri PL, Hayashizaki Y, Okado H, Hashimoto M, Asahara H. 2009. A systems approach reveals that the myogenesis genome network is regulated by the transcriptional repressor RP58. Developmental Cell 17:836-848. doi: 10.1016/j.devcel.2009.10.011.

Yonei-Tamura S, Abe G, Tanaka Y, Anno H, Noro M, Ide H, Aono H, Kuraishi R, Osumi N, Kuratani S, Tamura K. 2008. Competent stripes for diverse positions of limbs/fins in gnathostome embryos. Evolution \& Development 10:737-745. doi: 10.1111/j.1525-142X.2008.00288.x.

Zhang G, Cohn MJ. 2009. Scyliorhinus canicula Sox9 (Sox9) mRNA, complete cds. NCBI Nucleotide EU241880. http://www.ncbi.nlm.nih.gov/nuccore/EU241880.

Zhang J, Wagh P, Guay D, Sanchez-Pulido L, Padhi BK, Korzh V, Andrade-Navarro MA, Akimenko M-A. 2010. Loss of fish actinotrichia proteins and the fin-to-limb transition. Nature 466:234-237. doi: 10.1038/nature09137. 